\title{
RADIONUCLIDES IN THE GROUND-LEVEL AIR AND DEPOSITION IN THE IGNALINA NPP REGION DURING 2002 - 2005
}

\author{
R. Jasiulionis, A. Rožkov, and L. Vyčinas \\ Institute of Physics, Savanoriu 231, LT-02300 Vilnius, Lithuania \\ E-mail: rimjas@ktl.mii.lt,rozkov@ar.fi.lt
}

Received 5 December 2005

\begin{abstract}
Results of permanent measurements of ${ }^{7} \mathrm{Be},{ }^{137} \mathrm{Cs},{ }^{54} \mathrm{Mn}$, and ${ }^{60} \mathrm{Co}$ activity concentration in the ground-level air and deposition in the region of the Ignalina Nuclear Power Plant (INPP) in $2002-2005$ are presented. The activity concentrations of ${ }^{60} \mathrm{Co}$ in the ground-level air and deposition are analyzed and compared using a model of local transport based on semiempirical formulas and the Hybrid Single-Particle Lagrangian Integrated Trajectory (HYSPLIT) model of the global dispersion and deposition. Results of modelling are used for the determination of ${ }^{60} \mathrm{Co}$ activity distribution in the air and deposition in the Ignalina NPP region. The solubility in water of the aerosol-carriers of radionuclides in the ground-level air is investigated. It is shown that modelling results may be improved using different washout rates for water-soluble and insoluble radionuclides. The backward trajectories of air masses transport calculated using a HYSPLIT model show the Chernobyl NPP accident polluted area to be an additional source of ${ }^{137} \mathrm{Cs}$ in the INPP region.
\end{abstract}

Keywords: Ignalina Nuclear Power Plant, ${ }^{7} \mathrm{Be},{ }^{137} \mathrm{Cs},{ }^{54} \mathrm{Mn},{ }^{60} \mathrm{Co}$, radionuclides, modelling, HYSPLIT model, ground-level air, deposition

PACS: 89.60.Fe, 92.60.Sz

\section{Introduction}

Determining the unknown sources of radionuclides found in objects of the environment (air, deposition, etc.) is still a problem. The development of mathematical models, based on the results of the worldwide system of radioecological monitoring, using artificial radionuclides as tracers of air masses, can help much in solving this problem [1].

Part of radionuclides produced in fission, corrosion, and activation processes $\left({ }^{137} \mathrm{Cs},{ }^{54} \mathrm{Mn},{ }^{60} \mathrm{Co}\right.$, etc. $)$ in the Ignalina Nuclear Power Plant (INPP) technological systems permeate through technological barriers, are emitted through the $150 \mathrm{~m}$ high ventilation stack into the air. Therefore, the INPP becomes a permanent source of radionuclides emitted into the atmosphere. Experimental results of measurements of radionuclide activity concentration in the ground-level air and deposition in the environment of the INPP can be used for comparing the reliability of different mathematical transport models determining the radionuclides source. ${ }^{137} \mathrm{Cs}$ can also be transported to the INPP region with air masses passing the Chernobyl NPP accident polluted regions [2].
The aim of this study was to test the reliability of a Hybrid Single-Particle Lagrangian Integrated Trajectory (HYSPLIT) model of the global dispersion and deposition [3] to describe the distribution of radionuclides in the ground-level air and their deposition in the region of the Ignalina NPP by comparing experimental data with modelling results. The HYSPLIT model and a model of local transport based on semi-empirical formulas [4] were used. Besides, the possibility to apply the HYSPLIT model in determining the additional source of ${ }^{137} \mathrm{Cs}$ in the INPP region was shown.

\section{Method}

The air filtration equipment for continuous collection of aerosol-borne radionuclides is installed at the station of the Institute of Physics (PhI station)

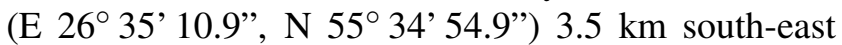

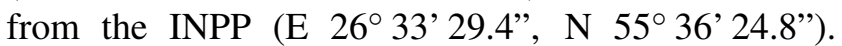
The high airflow rate of $1800 \mathrm{~m}^{3} / \mathrm{h}$ through the perchlorvinyl Petrianov filters with the $0.7 \mathrm{~m}^{2}$ area was used for aerosol sampling. Filters were pressed into pellets of stable geometry, and activities of radionuclides were measured by the gamma-spectrometry method. 
Meteorological data (wind velocity, direction, and air temperature at the height of 2 and 40 metres) from the meteorological station of the Ignalina NPP and HYSPLIT archive data from the Air Resources Laboratory (the USA) web site [3,5], as well as emission rates of radionuclides through the INPP stack were used in modelling the radionuclide distribution in the groundlevel air and deposition in the Ignalina NPP region.

The solubility in water of radionuclide compounds of aerosol samples was investigated. The pellet of the pressed filter was mechanically ground to powder, and $250 \mathrm{ml}$ of distilled water $(\mathrm{pH} \cong 7)$ was poured. After $18 \mathrm{~h}$ of extraction particles were separated using a "yellow ribbon" filter for medium-size deposits. Separated and dried up remainders of the pellet were pressed into the pellet of stable geometry. Filtrate was acidified with $2 \mathrm{ml}$ of $6 \mathrm{M} \mathrm{HNO}_{3}$ to avoid the radionuclide sorption on glass and evaporated to $10 \mathrm{ml}$ volume on the electric stove. This solution was poured on polyethylene film and slowly evaporated by heating with the electric bulb. Film was wrapped up into a sheet of the Petrianov filter, and the pellet of stable geometry was pressed. The effect of the diluted hydrochloric acid $(\mathrm{HCl})$ on pellets of "water-insoluble fraction" was also investigated to qualitatively evaluate the strength of radionuclide binding with aerosols. The pellet was mechanically chopped, and $250 \mathrm{ml}$ of $0.1 \mathrm{M} \mathrm{HCl}(\mathrm{pH} \cong 1$, pure grade) was poured. After $18 \mathrm{~h}$ the extract was filtered, evaporated, and pressed into the pellet.

A snow sample was collected on 23 January - 17 March 2005 from the $2 \mathrm{~m}^{2}$ area near the PhI station. A rain sample was collected on 20 April - 29 May 2005 from the sloping $10 \mathrm{~m}^{2}$ surface (roof of the $\mathrm{PhI}$ station) into the 801 bath inside the station.

A rapid precipitation method with the iron hydroxide was used to concentrate radionuclides $[2,6]$. Particles in the melted snow or rain samples were separated using the $0.1 \mathrm{~mm}$ diameter pore filter. The filtrate was treated radiochemically by adding iron (III), cobalt (II), manganese (II) salts and ammonia and adjusting the $\mathrm{pH}$ value in solution to 9. Then the sample was well mixed, left to stay overnight, and deposits of metal hydroxides were separated (snow or rain). Samples obtained from all operations were pressed into pellets of stable geometry, and activities of radionuclides were measured by the gamma-spectrometry method. In accordance with $[6,7]$ the ${ }^{137} \mathrm{Cs}$ yield was about $20 \%$. The iron amount in deposits was determined photometrically. The yield of iron deposits was calculated from the ratio between the standard iron amount added to the sample and that photometrically detected in deposits of metal hydrox- ides. As iron (III) salt was the main deposits agent, cobalt (II) and manganese (II) salts were added in much lower amounts, and yields of cobalt and manganese deposits were taken the same as the yield of iron deposits.

The total radionuclide activity concentration in deposition, $\mathrm{Bq} / \mathrm{m}^{2}$, was calculated by summing the radionuclide activity of particles ( $>0.1 \mathrm{~mm}$ diameter) and melted snow or rain filtrate activities and by normalizing the sample activity to the sampling surface area. The atmospheric precipitation amount fallen out during the sampling period was $120 \mathrm{~mm}$ in January March and $150 \mathrm{~mm}$ in April - May 2005.

The ORTEC portable gamma spectrometer with the HPGe detector and SILENA multichannel analyzer were used to obtain energy spectra of radionuclides.

\section{Results and discussion}

\subsection{Transport of radiocesium with air masses from the Chernobyl region}

Results of permanent observations of ${ }^{7} \mathrm{Be},{ }^{137} \mathrm{Cs}$, ${ }^{54} \mathrm{Mn}$, and ${ }^{60} \mathrm{Co}$ activity concentrations in the groundlevel air in the Ignalina NPP region from January 2002 to April 2005 are discussed. The course of ${ }^{7} \mathrm{Be}$ and ${ }^{137} \mathrm{Cs}$ activity concentrations in the ground-level air (2002 - 2005) is presented in Figs. 1 and 2.

The activity concentration of ${ }^{7} \mathrm{Be}$ in the air varied in the range of $0.5-9.7 \mathrm{mBq} / \mathrm{m}^{3}$. The increase in concentrations of ${ }^{7} \mathrm{Be}$ was observed in early summer and autumn. Apparently, descending of the stratospheric air to the boundary layer caused distinct increases in ${ }^{7} \mathrm{Be}$ concentrations [8].

Variations in the ${ }^{137} \mathrm{Cs}$ concentration probably depend on general global air mass mixing processes, the impact of the Ignalina NPP, and other potential distant sources. ${ }^{137} \mathrm{Cs}$ activity concentrations in the air were measured in the range of $0.1-3.0 \mu \mathrm{Bq} / \mathrm{m}^{3}$, but sometimes the activity concentrations of ${ }^{137} \mathrm{Cs}$ were higher than values of its global activity concentrations in the ground-level air. A detection recurrence of ${ }^{137} \mathrm{Cs}$ activity concentration in the air in $2002-2005$ in the range of $0.1-15 \mu \mathrm{Bq} / \mathrm{m}^{3}$ is presented in Fig. 3 .

The increase in the ${ }^{137} \mathrm{Cs}$ activity concentration in the air of up to $5-7 \mu \mathrm{Bq} / \mathrm{m}^{3}$ was observed in samples collected on 29 March - 8 April 2002; 16-22 March, 8-12 September, and 7-23 November 2003; 313 May, 20-27 June, 9-15 October 2004; 29 January 19 February 2005 . The ${ }^{137} \mathrm{Cs}$ activity concentration in remaining samples was even higher on 27 August 3 September $2002\left(10.3 \mu \mathrm{Bq} / \mathrm{m}^{3}\right)$; 19-26 April 2003 


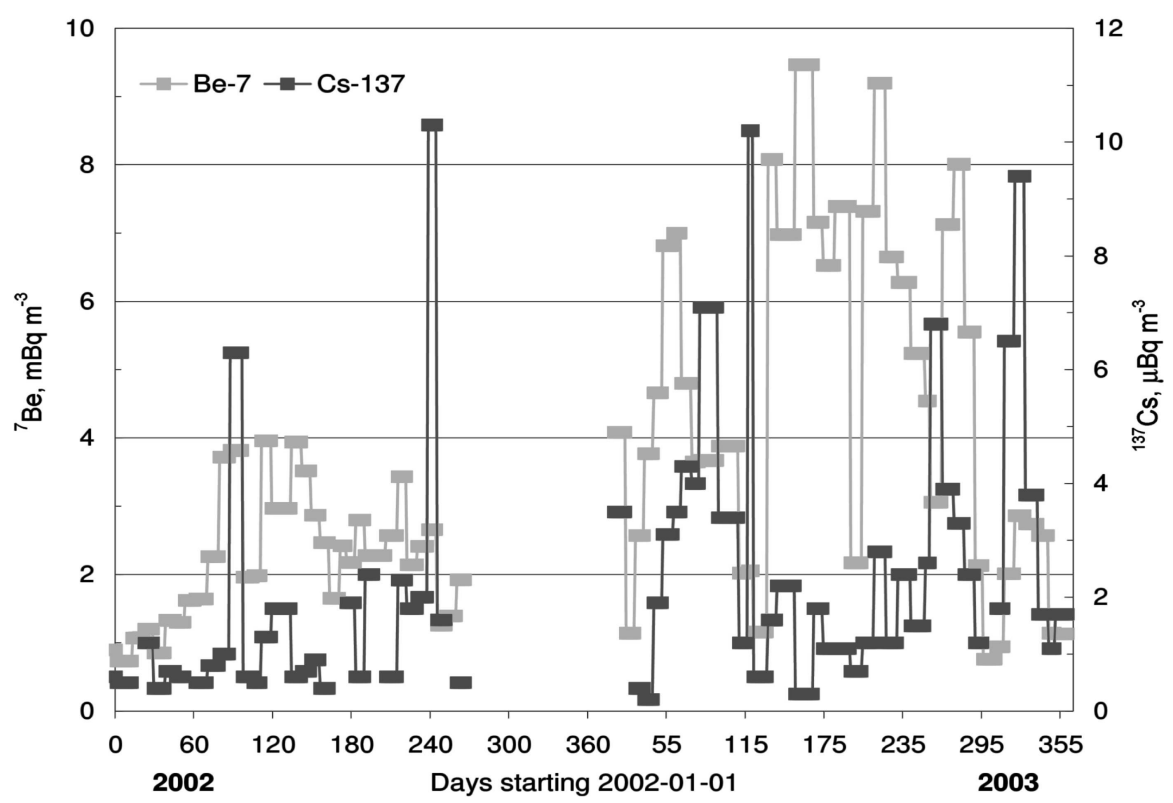

Fig. 1. Course of activity concentrations of ${ }^{137} \mathrm{Cs}, \mu \mathrm{Bq} / \mathrm{m}^{3}$, (right scale) and ${ }^{7} \mathrm{Be}, \mathrm{mBq} / \mathrm{m}^{3}$, (left scale) in the ground-level air in the region of the Ignalina NPP in $2002-2003$.

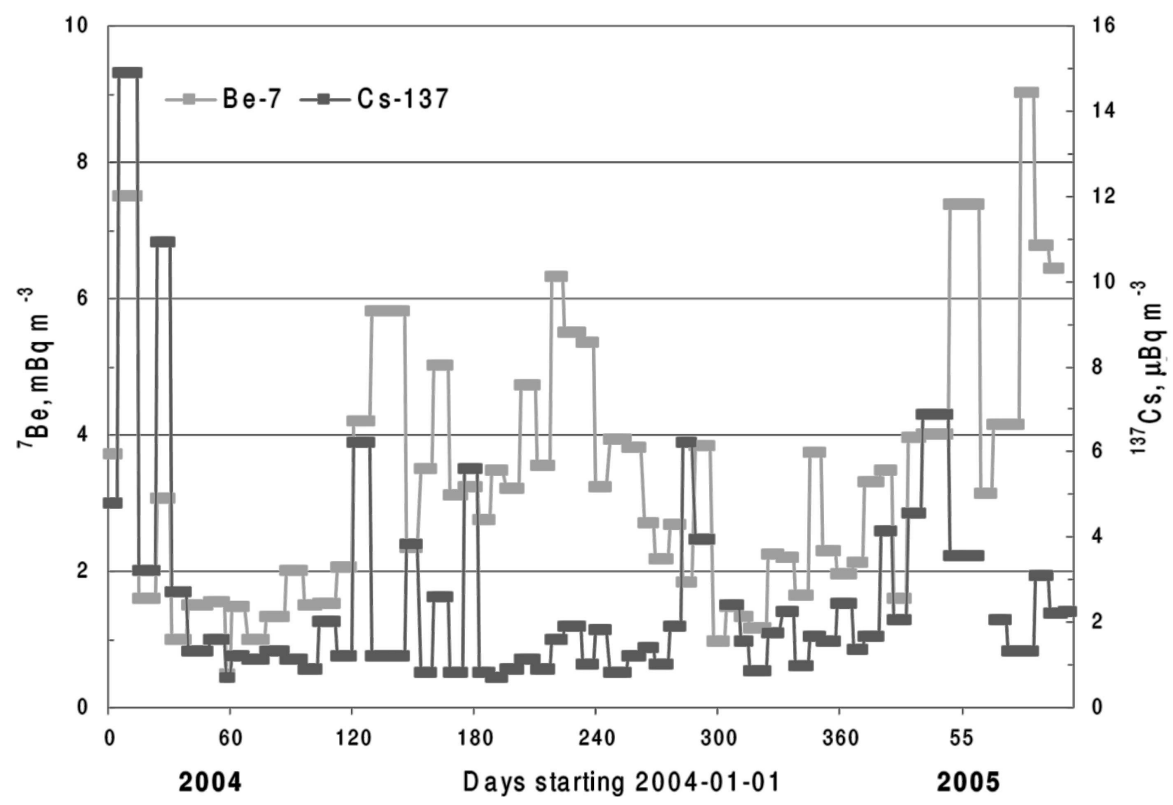

Fig. 2. Course of activity concentrations of ${ }^{137} \mathrm{Cs}, \mu \mathrm{Bq} / \mathrm{m}^{3}$, (right scale) and ${ }^{7} \mathrm{Be}, \mathrm{mBq} / \mathrm{m}^{3}$, (left scale) in the ground-level air in the region of the Ignalina NPP in $2004-2005$.

$\left(10.2 \mu \mathrm{Bq} / \mathrm{m}^{3}\right) ; 6-16$ January $\left(14.9 \mu \mathrm{Bq} / \mathrm{m}^{3}\right)$, and 25 January - 2 February $2004\left(10.9 \mu \mathrm{Bq} / \mathrm{m}^{3}\right)$.

The HYSPLIT model accessible at the Air Resources Laboratory web site [3] was used to determine the source of ${ }^{137} \mathrm{Cs}$ activity concentration increase in aerosol samples in the Ignalina NPP region. Air mass transport backward trajectories (for heights of 100, 500 , and $1000 \mathrm{~m}$ ) to the Ignalina NPP region were calculated for the 72 hour interval.

Two specific backward trajectories of air masses transported to the Ignalina NPP region on 17 November 2003 and 27 January 2004 are shown in Figs. 4 and 5.

These trajectories show that air masses came to the Ignalina region from the Chernobyl accident region causing the ${ }^{137} \mathrm{Cs}$ activity concentration increase in the ground-level air. The recurring coincidence of spasmodic increase in ${ }^{137} \mathrm{Cs}$ activity concentration in the air with transport of air masses from the Chernobyl region (registered earlier [9]) shows that the possible source of 


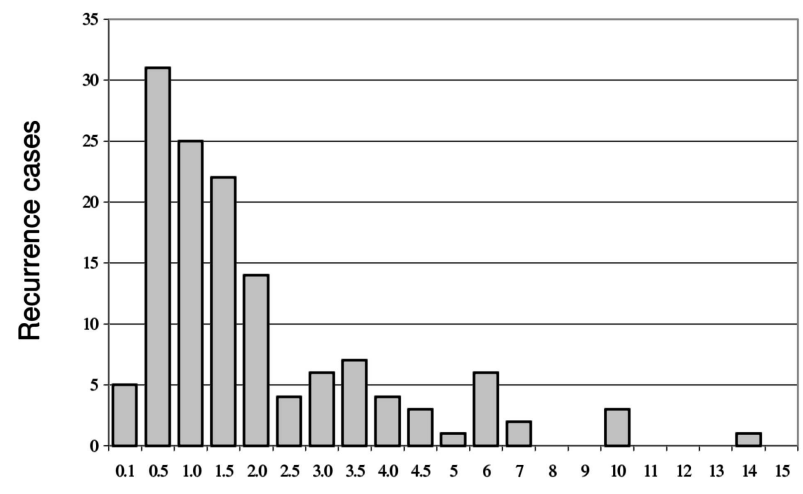

Activity concentration, $\mu \mathrm{Bq} \mathrm{m}{ }^{-3}$

Fig. 3. Recurrence cases of ${ }^{137} \mathrm{Cs}$ activity concentration in the ground-level air in the region of the Ignalina NPP in $2002-2005$.

\section{Backward trajectories starting at 12 UTC 17 Nov 03} FNL Meteorological Data

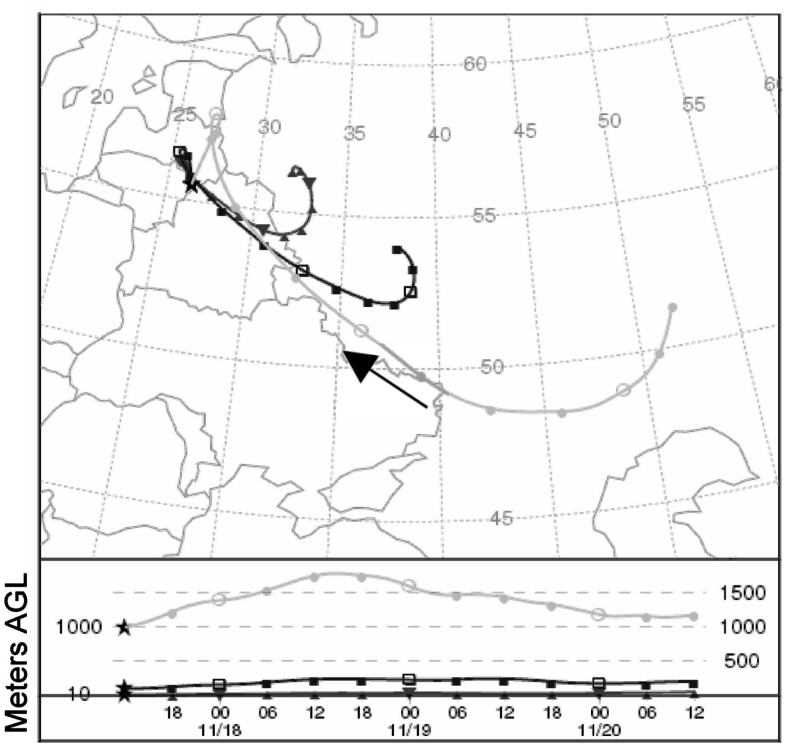

Fig. 4. Backward trajectory of air masses transported to the $\mathrm{Ig}$ nalina NPP region (17 November 2003, 12:00). An arrow shows the direction of air masses transport.

radionuclides that reached the observation region can be determined using the HYSPLIT model.

\subsection{Distribution of radionuclides emitted by the Ignalina NPP in the ground-level air}

Activity concentrations of ${ }^{60} \mathrm{Co}$ and ${ }^{54} \mathrm{Mn}$ emitted from the Ignalina NPP stack into the ground-level air from January 2002 to April 2005 were registered to be in the range of $0.1-7.5 \mu \mathrm{Bq} / \mathrm{m}^{3}$ (Table 1). The measurement error did not exceed $30 \%$.

Activity concentrations of ${ }^{60} \mathrm{Co}$ emitted by the Ignalina NPP were analyzed using a local model based on semi-empirical formulas for turbulent movement in
Backward trajectories ending at 12 UTC 27 Jan 04 FNL Meteorological Data

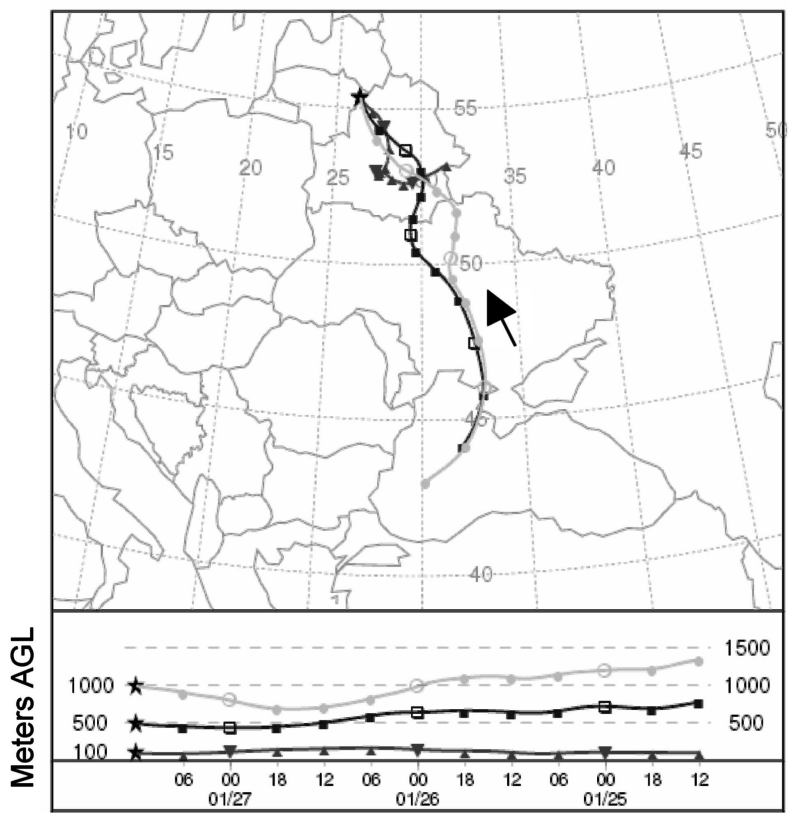

Fig. 5. Backward trajectory of air masses transported to the Ignalina NPP region (27 January 2004, 09:00). An arrow shows the direction of air masses transport.

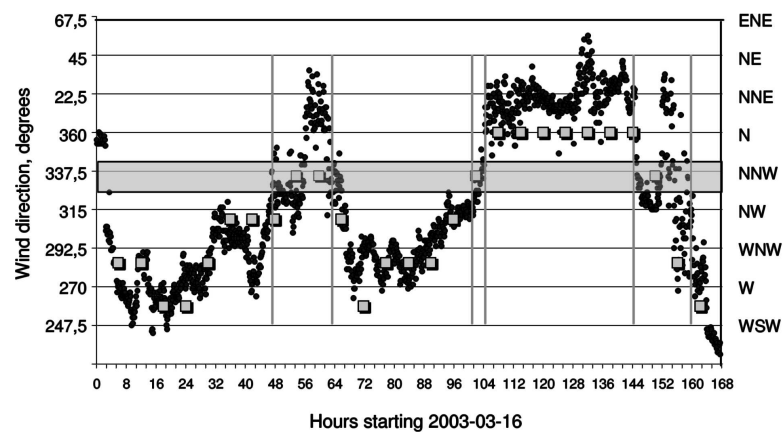

Fig. 6. Wind direction on 16 March 2003 during the aerosolborne radionuclide sampling $(\bullet$ - Ignalina NPP data and $\square-$ HYSPLIT archive data). Gray-scale belt corresponds to wind direction favourable for the $\mathrm{PhI}$ station.

the atmosphere [4] and the HYSPLIT modelling system of the global dispersion and deposition [3].

Comparison of meteorological data (wind velocity and direction as well as air temperature at the height of 2 and 40 metres) from the meteorological station of the Ignalina NPP and HYSPLIT archive data from the Air Resources Laboratory web site $[3,5]$ for the period of 16-22 March 2003 is presented in Fig. 6.

It is shown (Fig. 6) that courses of meteorological data from the meteorological station of the Ignalina NPP and HYSPLIT archive data are quite similar. In three periods (48 to 64, 100 to 104 , and 144 to 160 hours) the wind direction was from the Ignalina NPP to 
Table 1. Radionuclide activity concentrations in ground-level air in the INPP region in $2002-2005$.

\begin{tabular}{ccccc}
\hline \multirow{2}{*}{$\begin{array}{c}\text { Sampling } \\
\text { period }\end{array}$} & \multicolumn{4}{c}{ Activity concentration, $\mu \mathrm{Bq} / \mathrm{m}^{3}$} \\
\cline { 2 - 5 }${ }^{7} \mathrm{Be}$ & ${ }^{137} \mathrm{Cs}$ & ${ }^{54} \mathrm{Mn}$ & ${ }^{60} \mathrm{Co}$ \\
\hline $2002.08 .19-08.27$ & $2140 \pm 20$ & $1.8 \pm 0.3$ & $<0.1$ & $4.8 \pm 1.2$ \\
$2003.03 .16-03.22$ & $3650 \pm 50$ & $4.0 \pm 1.0$ & $<0.1$ & $0.9 \pm 0.2$ \\
$2003.08 .18-08.28$ & $6280 \pm 60$ & $2.4 \pm 0.6$ & $1.9 \pm 0.5$ & $2.3 \pm 0.6$ \\
$2003.09 .08-09.12$ & $4540 \pm 15$ & $2.6 \pm 0.4$ & $1.9 \pm 0.6$ & $5.9 \pm 1.7$ \\
$2003.11 .07-11.15$ & $2010 \pm 20$ & $6.5 \pm 1.5$ & $3.4 \pm 1.0$ & $6.5 \pm 1.8$ \\
$2004.03 .20-03.30$ & $1320 \pm 25$ & $2.3 \pm 0.5$ & $<0.1$ & $0.9 \pm 0.2$ \\
$2004.07 .26-08.03$ & $3540 \pm 35$ & $1.3 \pm 0.3$ & $1.1 \pm 0.3$ & $1.3 \pm 0.2$ \\
$2004.10 .24-10.31$ & $960 \pm 40$ & $<0.1$ & $<0.1$ & $7.5 \pm 1.4$ \\
$2005.01 .02-01.08$ & $2120 \pm 20$ & $1.4 \pm 0.4$ & $<0.1$ & $2.2 \pm 0.3$ \\
\hline
\end{tabular}

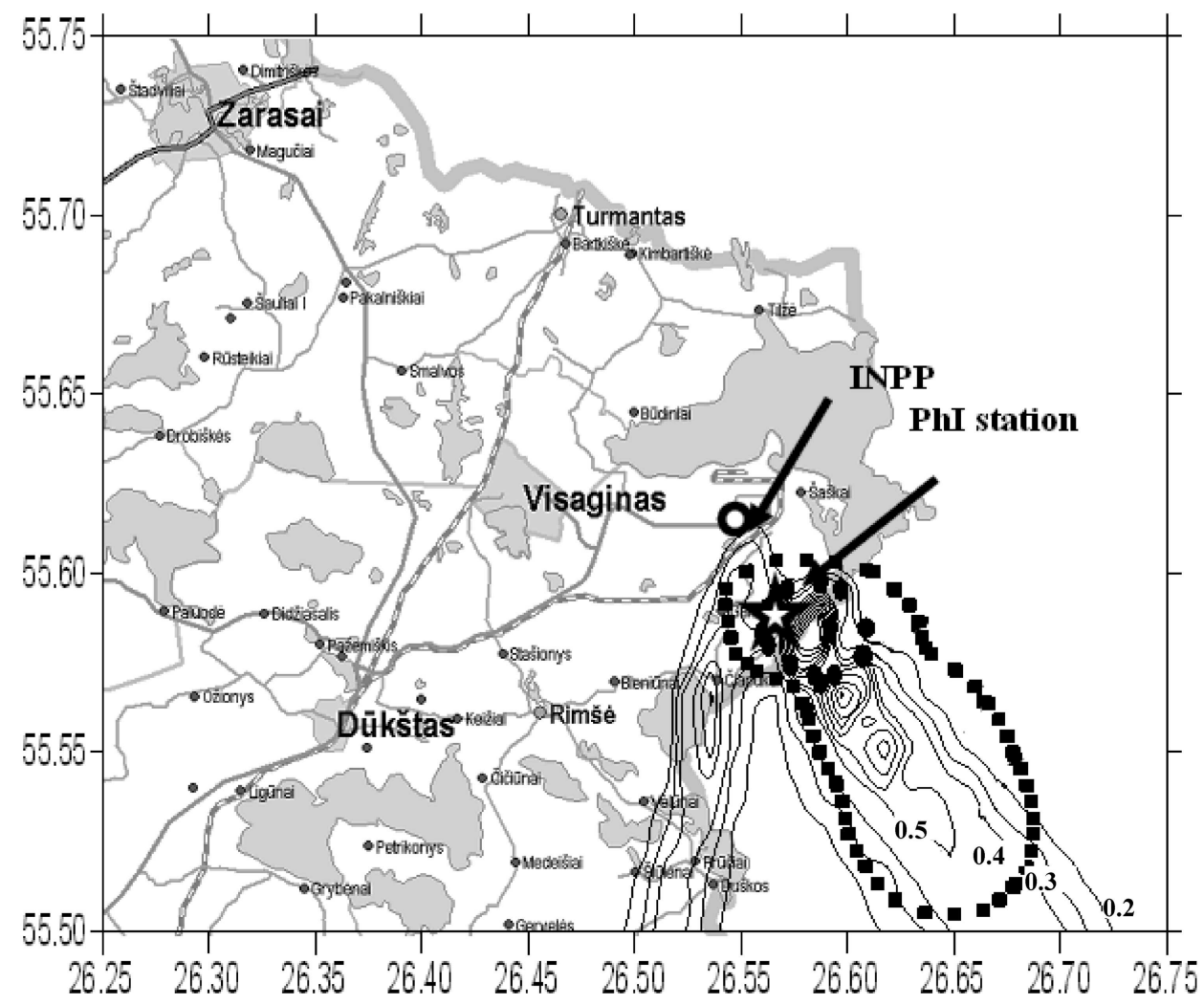

Fig. 7. Calculated distribution of ${ }^{60} \mathrm{Co}$ activity concentration in the ground-level air on $18 \mathrm{March} 2003$. $\bullet-$ the contour of ${ }^{60} \mathrm{Co}$ activity concentration calculated by a HYSPLIT model $\left(0.1 \mu \mathrm{Bq} / \mathrm{m}^{3}\right) ; \mathbf{\square}$ - the contour of ${ }^{60} \mathrm{Co}$ activity concentration calculated by a HYSPLIT model $\left(0.02 \mu \mathrm{Bq} / \mathrm{m}^{3}\right)$; isolines $-{ }^{60} \mathrm{Co}$ activity concentrations calculated using a model of local transport $\left(0.2-1 \mu \mathrm{Bq} / \mathrm{m}^{3}\right)$.

the $\mathrm{PhI}$ station. The ${ }^{60} \mathrm{Co}$ activity concentrations in the air for these periods were calculated using two models mentioned above (Fig. 7).

According to the modelling results the ${ }^{60} \mathrm{Co}$ activity concentration in the air for the PhI station on 1622 March 2003 calculated by the HYSPLIT model was $0.1 \mu \mathrm{Bq} / \mathrm{m}^{3}$, calculated by the model of local transport it was $0.8 \mu \mathrm{Bq} / \mathrm{m}^{3}$, and the measured one was $0.87 \pm$ $0.17 \mu \mathrm{Bq} / \mathrm{m}^{3}$.

Calculated ${ }^{60} \mathrm{Co}$ activity concentration in the ground-level air using a model of local transport was similar to its activity concentration measured in the aerosol sample. The HYSPLIT model underestimated ${ }^{60} \mathrm{Co}$ activity concentration in the air near the PhI station. Apparently, more measurements are needed in order to explain the disagreement between the HYSPLIT model calculation data and the experimental results.

\subsection{Radionuclide fractions in aerosol samples}

Compounds of ${ }^{137} \mathrm{Cs},{ }^{60} \mathrm{Co}$, and ${ }^{54} \mathrm{Mn}$ radionuclides in the Ignalina NPP ventilation stack were mainly 


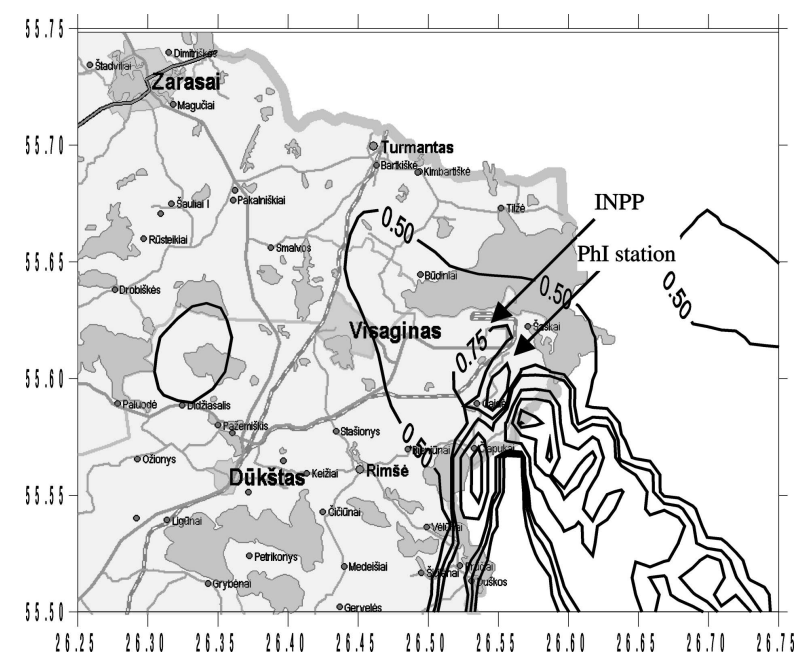

Fig. 8. Distribution of mean ${ }^{60} \mathrm{Co}$ activity concentrations (waterinsoluble fraction) in the ground-level air $\left(\mu \mathrm{Bq} / \mathrm{m}^{3}\right)$ on $20-30$

March 2004. The aerosol washout rate of $0.2 \mathrm{~cm} / \mathrm{s}$ was used.

water-soluble according to the investigation results of four aerosol samples, while in the ground-level air these radionuclides were found mostly in waterinsoluble fraction of aerosol samples [2]. In this paper the results of the investigation of aerosol solubility in water collected in $2004-2005$ are presented.

Activity concentrations of radionuclides in watersoluble and insoluble fractions of aerosol samples, $\mu \mathrm{Bq} / \mathrm{m}^{3}$, and percentage quantity of radionuclides in water-insoluble fraction are given in Table 2 . The measurement error did not exceed $30 \%$.

Referring to the results in Table 2, only one fifth of ${ }^{60} \mathrm{Co}$ aerosol-carriers and one third of ${ }^{137} \mathrm{Cs}$ aerosolcarriers found in the aerosol filters dissolve in distilled water. ${ }^{54} \mathrm{Mn}$ was found in one sample in waterinsoluble form only.

After extracting water-insoluble fraction with $0.1 \mathrm{M}$ $\mathrm{HCl}$ solution the ${ }^{60} \mathrm{Co}$ elution level was in the range of $12-31 \%$, and that of ${ }^{54} \mathrm{Mn}$ was $11 \%$. According to these preliminary results ${ }^{137} \mathrm{Cs},{ }^{60} \mathrm{Co}$, and ${ }^{54} \mathrm{Mn}$ are mostly in water-insoluble aerosols in the ground-level air in the Ignalina NPP region. ${ }^{60} \mathrm{Co}$ and ${ }^{54} \mathrm{Mn}$ are strongly bound with aerosols, and $0.1 \mathrm{M} \mathrm{HCl}$ does not affect them significally.

Washout coefficients for water-soluble and insoluble fractions of radionuclides [2] were used for calculation of the distribution of the ${ }^{60} \mathrm{Co}$ radionuclide activity concentration in the ground-level air on 20-30 March 2004 (Figs. 8 and 9) using a semi-empirical turbulent diffusion model [4].

Results of calculation show that using a different washout rate for insoluble and soluble aerosol the experimental data can be explained. On the contrary, the

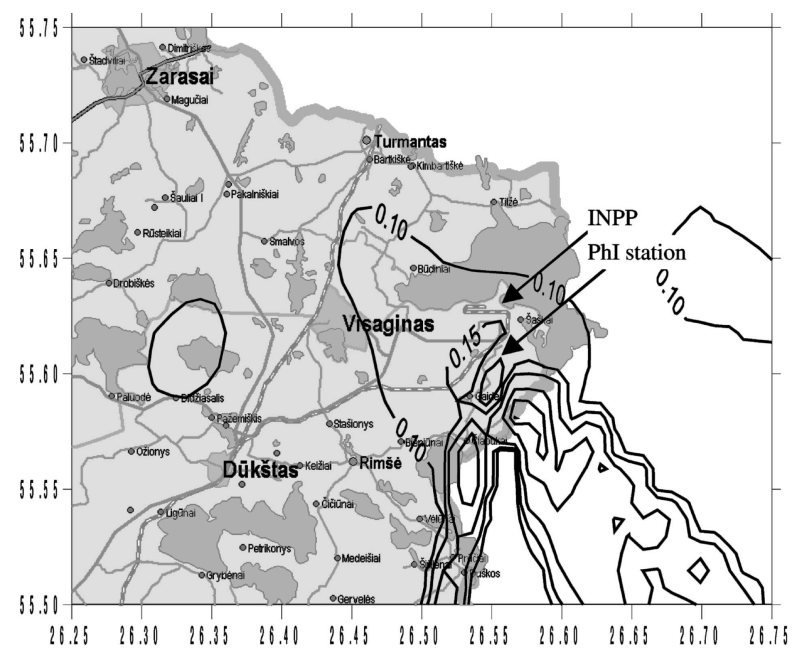

Fig. 9. Distribution of mean ${ }^{60} \mathrm{Co}$ activity concentrations (watersoluble fraction) in the ground-level air $\left(\mu \mathrm{Bq} / \mathrm{m}^{3}\right)$ on 20-30 March 2004. The aerosol washout rate of $0.1 \mathrm{~cm} / \mathrm{s}$ was used.

continuation of the investigation on the solubility of aerosols in water enables us to correct existing washout rates and improve the model of local transport. Therefore, more investigations on aerosol solubility in water are needed.

\subsection{Radionuclide activity concentrations in deposition}

Activities of radionuclides in deposition samples, $\mathrm{Bq}$, and their deposition densities, $\mathrm{Bq} / \mathrm{m}^{2}$, are given in Table 3. The yield of iron (III) hydroxide deposits was $75-76 \%$. The measurement error did not exceed $30 \%$.

${ }^{60} \mathrm{Co}$ and ${ }^{137} \mathrm{Cs}$ were detected in particles of more than $0.1 \mathrm{~mm}$ diameter size and in the solution of deposition. The ratio between ${ }^{60} \mathrm{Co}$ in particles and dissolved in the melted snow water was 1:5. The ratio between ${ }^{137} \mathrm{Cs}$ in particles and dissolved in the melted snow water and in the rain water was 1:7 and 1:10, respectively. ${ }^{60} \mathrm{Co}$ compounds were mostly concentrated in snow, however, in the rain sample ${ }^{60} \mathrm{Co}$ activity concentration was lower than the detection limit $0.05 \mathrm{~Bq} / \mathrm{m}^{2}$.

Distribution of ${ }^{60} \mathrm{Co}$ activity concentrations, $\mathrm{Bq} / \mathrm{m}^{2}$, in snow in the Ignalina NPP region on 23 January -17 March 2005, is presented in Fig. 10.

Results of measurements of radionuclide activity concentrations in deposition at the $\mathrm{PhI}$ station enable us to evaluate radionuclide distribution in deposition in the Ignalina NPP region using a model of local transport. A study of the possibility of using the HYSPLIT model to describe the distribution of radionuclides in deposition in the INPP region is needed. 
Table 2. Radionuclide activity concentrations in water-soluble and insoluble fractions of aerosol samples collected at the $\mathrm{PhI}$ station in $2002-2005$.

\begin{tabular}{|c|c|c|c|c|}
\hline \multirow{2}{*}{$\begin{array}{l}\text { Sampling } \\
\text { period }\end{array}$} & \multirow[t]{2}{*}{ Radionuclide } & \multicolumn{2}{|c|}{ Activity concentration, $\mu \mathrm{Bq} / \mathrm{m}^{3}$} & \multirow{2}{*}{$\begin{array}{c}\text { Percentage quantity in } \\
\text { water-insoluble fraction, } \%\end{array}$} \\
\hline & & Water-soluble fraction & Water-insoluble fraction & \\
\hline \multirow{2}{*}{ 2004.03.20-30 } & ${ }^{137} \mathrm{Cs}$ & $0.9 \pm 0.15$ & $1.4 \pm 0.25$ & 61 \\
\hline & ${ }^{60} \mathrm{Co}$ & $0.2 \pm 0.05$ & $0.7 \pm 0.25$ & 78 \\
\hline \multirow{3}{*}{$2004.07 .26-08.03$} & ${ }^{137} \mathrm{Cs}$ & $0.4 \pm 0.1$ & $0.9 \pm 0.1$ & 69 \\
\hline & ${ }^{54} \mathrm{Mn}$ & $<0.1$ & $1.1 \pm 0.2$ & 100 \\
\hline & ${ }^{60} \mathrm{Co}$ & $0.3 \pm 0.05$ & $1.0 \pm 0.2$ & 77 \\
\hline \multirow{2}{*}{$2005.01 .02-08$} & ${ }^{137} \mathrm{Cs}$ & $0.4 \pm 0.1$ & $1.0 \pm 0.3$ & 71 \\
\hline & ${ }^{60} \mathrm{Co}$ & $0.5 \pm 0.1$ & $1.7 \pm 0.3$ & 77 \\
\hline
\end{tabular}

Table 3. Radionuclide activity concentrations in deposition and their deposition densities (b. d. 1. - below detection limit).

\begin{tabular}{clcccc}
\hline \multirow{2}{*}{$\begin{array}{c}\text { Sampling } \\
\text { period }\end{array}$} & Sample & \multicolumn{2}{c}{ Activity, Bq } & \multicolumn{2}{c}{ Total deposition density, Bq $\mathrm{m}^{2}$} \\
\cline { 3 - 6 } & & ${ }^{137} \mathrm{Cs}$ & ${ }^{60} \mathrm{Co}$ & ${ }^{137} \mathrm{Cs}$ & ${ }^{60} \mathrm{Co}$ \\
\hline \multirow{2}{*}{$2005.01 .23-03.17$} & Particles (size $>0.1 \mathrm{~mm}$ diameter) & $0.12 \pm 0.02$ & $0.04 \pm 0.005$ & $0.85 \pm 0.2$ & $0.12 \pm 0.01$ \\
& Snow (160 L) & $1.10 \pm 0.30$ & $0.25 \pm 0.015$ & & \multirow{2}{*}{ b. d. 1.} \\
\hline \multirow{2}{*}{$2005.04 .20-05.29$} & Particles (size $>0.1 \mathrm{~mm}$ diameter) & $0.17 \pm 0.50$ & b.d.1. & $1.96 \pm 0.6$ & \\
& Rain (80 L) & $1.00 \pm 0.30$ & & & \\
\hline
\end{tabular}

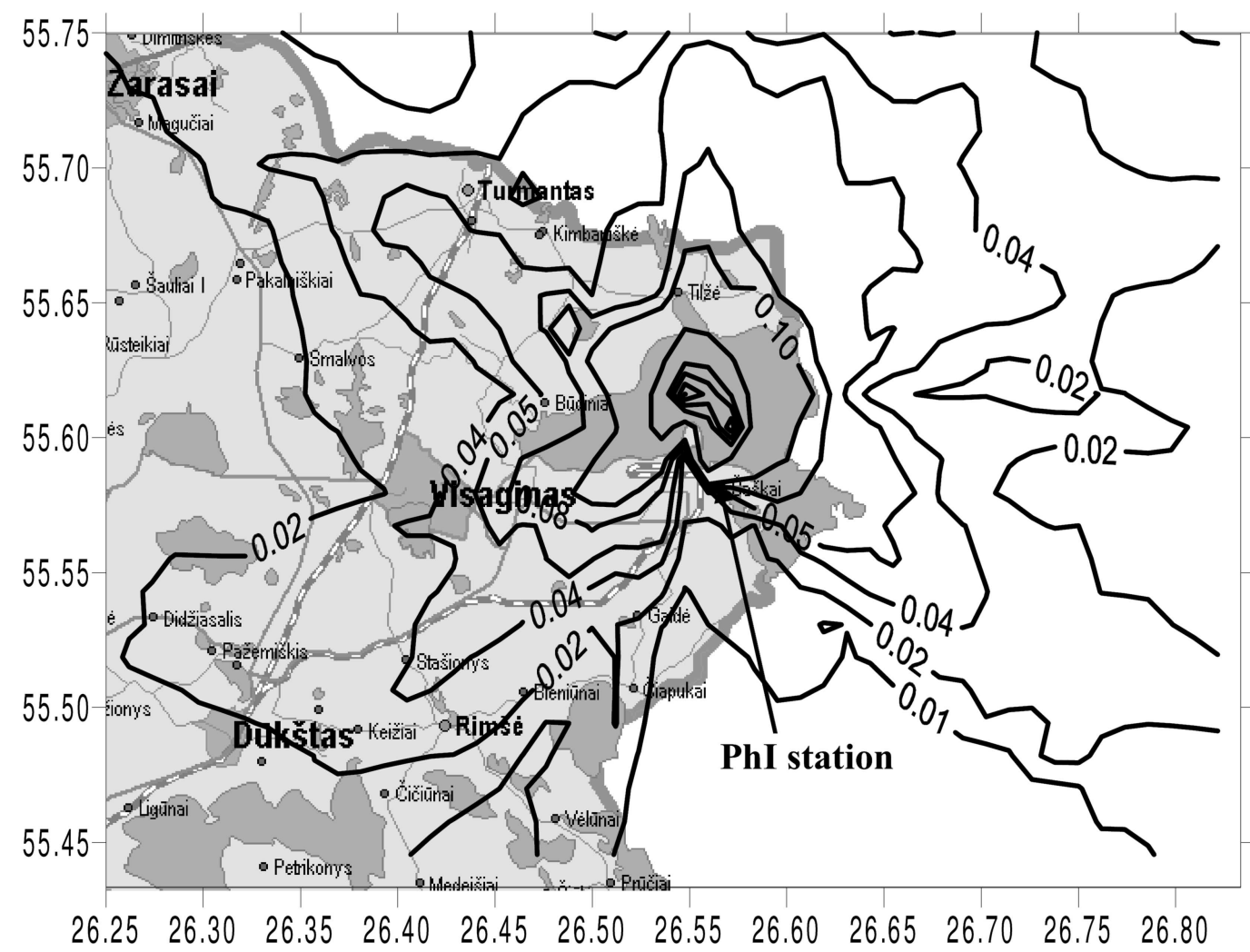

Fig. 10. Distribution of ${ }^{60} \mathrm{Co}$ activity concentrations, $\mathrm{Bq} / \mathrm{m}^{2}$, in deposition (snow) in the Ignalina NPP region on $23 \mathrm{January}-17 \mathrm{March}$ 2005. 


\section{Conclusions}

It is shown that a model of local transport can be used to calculate activity concentrations of radionuclides in the ground-level air on a local scale and to calculate dispersion of radionuclides emitted through the Ignalina NPP stack. The HYSPLIT model of the global dispersion and deposition underestimates the radionuclide activity concentration in the ground-level air in the Ignalina NPP region. There is a necessity to carry out more investigations in order to evaluate the possibility of using the HYSPLIT model for the calculation of radionuclide activity concentration distribution in the ground-level air and deposition on a local scale.

${ }^{60} \mathrm{Co}$ and ${ }^{54} \mathrm{Mn}$ radionuclides in the Ignalina NPP ground-level air are mostly found in compounds with water-insoluble aerosols. Modelling results of radionuclide distribution in the INPP region may be improved by continuing investigations on their solubility in water.

It is shown that backward trajectories of air mass transport calculated using the HYSPLIT model can be used to explain the increase in ${ }^{137} \mathrm{Cs}$ activity concentrations in ground-level air higher than their variations caused by global processes and to determine the possible source of ${ }^{137} \mathrm{Cs}$ in the Ignalina NPP region.

\section{Acknowledgement}

This work was supported by the Lithuanian State Science and Studies Foundation under the project No. C-19/2003.

\section{References}

[1] J. Schulze, M. Auer, and R. Werzi, Low level radioactivity measurement in support of the CTBTO, Appl. Radiation Isotopes 53(1-2), 23-30 (2000).

[2] R. Jasiulionis and I. Savickaite, Radionuclides in ground-level air and deposits near Ignalina NPP, Nukleonika 46(4), 183-187 (2001).

[3] R.R. Draxler and G.D. Hess, An overview of the HYSPLIT4 modeling system for trajectories, dispersion and deposition, Aust. Met. Mag. 47, 295-308 (1998). www .arl.noaa.gov/ready/hysplit4.html .

[4] R. Jasiulionis, Modeling of atmospheric admixture dispersion for determination of the relationship between radionuclide emission and concentrations in the boundary air layer, Environmental Phys. 20(1), 27-33 (1988).

[5] R.R. Draxler, Boundary layer isentropic and kinematic trajectories during the August 1993 North Atlantic Regional Experiment Intensive, J. Geophys. Res. 101(D22), 29255-29268 (1996).

[6] V. Kuznecov and V. Generalova, Sorption of ${ }^{90} \mathrm{Sr}$ and ${ }^{137} \mathrm{Cs}$ on silica and iron, manganese, titanium and aluminium hydroxides, Radiochemistry 42(2), 154-157 (2000) [in Russian].

[7] R. Jasiulionis, A. Gudelis, I. Savickaite, and D. Marčiulioniene, Radionuclides in the Lake Drūkšiai - the cooling basin of the Ignalina NPP, Atmos. Phys. 17(1), 2529 (1995).

[8] V. Lujanas, Cosmogenic Radionuclides in the Atmosphere (Mokslas, Vilnius, 1979) [in Russian].

[9] R. Jasiulionis, Aerosol-borne radionuclides in the ground-level air near the Ignalina NPP, Environmental Chem. Phys. 25(1), 23-29 (2003).

\title{
RADIONUKLIDAI PAŽEMIO ORE IR IŠKRITOSE IGNALINOS AE APLINKOJE 2002 - 2005 M.
}

\author{
R. Jasiulionis, A. Rožkov, L. Vyčinas \\ Fizikos institutas, Vilnius, Lietuva
}

\section{Santrauka}

Pateikiami ${ }^{7} \mathrm{Be},{ }^{137} \mathrm{Cs},{ }^{54} \mathrm{Mn}$ ir ${ }^{60} \mathrm{Co}$ aktyvumo koncentraciju pažemio ore nuolatinių matavimų Ignalinos AE regione 2002 2005 metais rezultatai. ${ }^{60} \mathrm{Co}$ aktyvumo koncentracijos pažemio ore ir iškritose analizuotos ir palygintos naudojant lokalų pernašos ir globalų HYSPLIT modelius. Remiantis modeliavimo rezultatais, ivertintas ${ }^{60} \mathrm{Co}$ pasiskirstymas Ignalinos AE regione. Aptariami radionuklidu aerozolinès frakcijos tirpumo vandenyje rezultatai. Galimam padidintų ${ }^{137} \mathrm{Cs}$ aktyvumo koncentracijų ore šaltiniui nustatyti panaudotas HYSPLIT modelis oro masių pernašos i Ignalinos AE regioną trajektorijoms skaičiuoti. 